\title{
Pola kuman dari infeksi luka operasi pada pasien multitrauma
}

\author{
${ }^{1}$ Sidhit Barung, ${ }^{2}$ Heber B. Sapan, ${ }^{2}$ Winfrid M. Sumanti, ${ }^{2}$ Rudy Tubagus
}

\author{
${ }^{1}$ Program Studi Ilmu Bedah Fakultas Kedokteran Universitas Sam Ratulangi Manado \\ ${ }^{2}$ KSM Ilmu Bedah Divisi Bedah Digestif RSUP Prof. Dr. R. D. Kandou Manado \\ ${ }^{3}$ KSM Ilmu Bedah RSUP Prof. Dr. R. D. Kandou Manado \\ Email: sidhit_barung@yahoo.co.id
}

\begin{abstract}
Surgical site infection (SSI) is the main surgery complication which can increase morbidity, mortality, as well as the hospital cost. The prevalence of SSIs at a health care reflects its sevice quality. This study was aimed to obtain the bacterial profile of SSIs among multitraumatic patients at Prof. Dr. R. D. Kandou Hospital from June through December 2016. This was a descriptive study with a cross sectional design. Pus was obtained from SSIs of laparotomy and ORIF operation wounds, and was further examined with PCR. The results showed that of 16 samples, 3 samples were negative (18.75\%) and 13 samples were positive $(81.25 \%)$. The PCR test showed that the highest percentage of bacteria was Pseudomonas aeruginosa (6 samples; 46.1\%), followed by Escherichia coli (2 samples; 15.4\%), and Enterobacter hormaechei, Alcaligenes faecalis, Enterobacter cloacae, Bacteroides fragilis as well as Proteus mirabilis (each of 1 sample; 7.7\%). Conclusion: Based on the PCR test, there were 7 types of bacteria at the SSIs of multitraumatic patients at Prof. Dr. R. D. Kandou Hospital Manado, all of them were Gram negative, and the most common type was Pseudomonas aeruginosa.
\end{abstract}

Keywords: bacterial profile, PCR, SSIs, multitraumatic patients

\begin{abstract}
Abstrak: Infeksi luka operasi merupakan salah satu komplikasi utama operasi yang dapat meningkatkan morbiditas, mortalitas, dan biaya perawatan penderita di rumah sakit. Angka kejadian infeksi luka operasi pada suatu institusi penyedia pelayanan kesehatan mencerminkan kualitas pelayanan pada institusi tersebut. Penelitian ini bertujuan untuk mendapatkan pola kuman infeksi luka operasi pada pasien multitrauma di ruang perawatan bedah RSUP Prof. Dr. R. D. Kandou selama bulan Juni-Desember 2016. Jenis penelitian ialah deskriptif dengan desain potong lintang. Apusan pus diambil dari luka operasi terinfeksi pada tindakan laparotomi dan ORIF kemudian diperiksa dengan PCR. Hasil penelitian memperlihatkan dari 16 sampel yang diteliti ditemukan 3 sampel negatif $(18,75 \%)$ dan 13 sampel positif $(81,25 \%)$. Berdasarkan hasil PCR ditemukan pertumbuhan kuman terbanyak ialah Pseudomonas aeruginosa sejumlah 6 sampel (46,1\%), diikuti Escherichia coli sejumlah 2 sampel $(15,4 \%)$, serta Enterobacter hormaechei, Alkaligenes faecalis, Enterobacter cloacae, Bacteroides fragilis, dan Proteus mirabilis, masing-masing sejumlah 1 sampel (7,7\%). Simpulan: Berdasarkan hasil PCR didapatkan 7 jenis kuman pada infeksi luka operasi dari pasien multitrauma di RSUP Prof. Dr. R. D. Kandou Manado, kesemuanya tergolong bakteri Gram negatif, dan yang tersering ialah Pseudomonas aeruginosa.
\end{abstract}

Kata kunci: pola kuman, PCR, infeksi luka operasi, pasien multitrauma

Ilmu bedah berkaitan erat dengan ilmu infeksi bedah. Di masa lalu, tindakan bedah banyak mengalami komplikasi infeksi. Pada saat itu pencegahan infeksi belum dilakukan karena mekanisme infeksi belum diketahui. Pencucian tangan dengan klorin sebelum tindakan pembedahan dan penelitian mengenai infeksi akibat tindakan 
pembedahan dipelopori oleh Semmelweis pada tahun $1847 .^{1,2}$

Infeksi luka operasi merupakan salah satu komplikasi utama operasi yang dapat meningkatkan morbiditas, mortalitas, dan biaya perawatan penderita di rumah sakit. Angka kejadian infeksi luka operasi pada suatu institusi penyedia pelayanan kesehatan mencerminkan kualitas pelayanan pada institusi tersebut. Survei WHO menunjukkan bahwa angka kejadian infeksi luka operasi di dunia berkisar antara 5\% sampai $34 \% .^{3}$

Komplikasi pada luka operasi sering terjadi karena pembedahan yang merupakan tindakan dengan sengaja membuat luka pada jaringan sehingga memberi suatu tempat jalan masuk untuk bakteri; hal ini membutuhkan tingkat sterilitas yang maksimal. Infeksi luka operasi dibagi atas superfisial, dalam, dan organ, sehingga penanganannya juga berbeda. Infeksi luka operasi dapat disebabkan oleh berbagai bakteri, yaitu bakteri Gram negatif, bakteri Gram positif, dan bakteri anaerob. ${ }^{1,2}$

Infeksi luka operasi berhubungan dengan morbiditas yang cukup besar dan telah dilaporkan bahwa lebih dari sepertiga kematian pasca operasi disebabkan karena infeksi luka operasi. Penting untuk disadari bahwa infeksi luka operasi dapat merupakan luka yang relatif ringan tanpa komplikasi sampai pada kondisi lain yang mengancam jiwa. Hasil klinis lain dari infeksi luka operasi termasuk bekas luka buruk yang secara kosmetik tidak dapat diterima, seperti hipertrofi atau keloid, nyeri dan gatal, terbatasnya gerakan, terutama bila terjadi di atas sendi. ${ }^{4}$

Infeksi luka operasi dapat melipatgandakan lamanya waktu pasien dirawat di rumah sakit dan dengan demikian meningkatkan biaya perawatan kesehatan. Biaya tambahan yang timbul akibat infeksi luka operasi telah dilaporkan tergantung pada jenis operasi dan tingkat keparahan infeksi. Biaya tambahan utama terkait dengan operasi ulang, perawatan ekstra keperawatan dan intervensi, serta biaya pengobatan. Biaya tidak langsung diakibatkan oleh hilangnya produktivitas ketidakpuasan pasien, dan berkurangnya kualitas hidup. ${ }^{4}$

Multitrauma adalah cedera yang melibatkan 2 regio tubuh atau lebih, salah satunya dapat mengancam nyawa termasuk cedera dengan injury severity score (ISS) $\geq 16$, atau cedera kompleks pada kedua ekstremitas bawah, atau kombinasi cedera yang melibatkan satu ekstremitas atas dan satu lagi pada ekstremitas bawah, dimana ekstremitas bawah tidak dapat digunakan menopang tubuh, ataupun cedera kompleks pada pelvis. $^{2}$

Metode yang paling umum untuk mengindetifikasi spesies kuman ialah metode kultur dengan menggunakan media agar yang memungkinkan untuk identifikasi dan diferensiasi spesies kuman. Seiring dengan perkembangan ilmu pengetahuan dan teknologi dalam biologi molekuler yang telah menghasilkan kemajuan sangat pesat dengan menggunakan metode terbaru yaitu mesin polymerase chain reaction (PCR) yang memungkinkan identifikasi sangat cepat, relatif mudah, sensitif dan spesifik, tetapi dengan biaya yang mahal. ${ }^{4}$

\section{METODE PENELITIAN}

Penelitian dilakukan terhadap infeksi luka operasi pada pasien multitrauma di ruang perawatan bedah IBS, OK cito dan Irina A RSUP Prof. Dr. R. D. Kandou Manado selama bulan Juni-Desember 2016. Jenis penelitian ini ialah deskriptif.

Pada penelitian ini dilakukan pemeriksaan cairan pus dari infeksi luka operasi laparotomi dan open reduction internal fixation (ORIF) dengan menggunakan metode PCR.

\section{HASIL PENELITIAN}

Pada penelitian ini didapatkan 16 pasien dengan infeksi luka operasi. Berdasarkan besaran kuman yang didapat dari hasil PCR, pada 16 jumlah sampel yang diteliti ditemukan 3 sampel negatif $(18,75 \%)$ dan 13 sampel positif $(81,25 \%)$ (Tabel 1).

Penelitian ini dilakukan pada jenis tindakan operasi laparotomi dan (ORIF). 
Dari 11 tindakan laparotomi di temukan 11 positif PCR sedangkan pada 5 tindakan ORIF ditemukan 2 positif PCR (Tabel 2).

Tabel 1. Hasil PCR kuman yang diambil dari luka operasi yang terinfeksi

\begin{tabular}{ccc}
\hline $\begin{array}{c}\text { Hasil PCR } \\
\text { kuman }\end{array}$ & $\begin{array}{c}\text { Jumlah sampel } \\
(\mathbf{n})\end{array}$ & $\%$ \\
\hline Positif & 13 & 81,25 \\
Negatif & 3 & 18,75 \\
Total & 16 & 100 \\
\hline
\end{tabular}

Tabel 2. Hasil kultur kuman berdasarkan jenis tindakan operasi

\begin{tabular}{cccc}
\hline $\begin{array}{c}\text { Tindakan } \\
\text { operasi }\end{array}$ & Positif & Negatif & Total \\
\hline Laparotomi & 11 & 0 & 11 \\
ORIF & 2 & 3 & 5 \\
Total & 13 & 3 & 16 \\
\hline
\end{tabular}

Dari 13 jumlah sampel yang positif PCR, terdapat 7 macam spesies kuman (Tabel 3). Berdasarkan hasil PCR, kuman terbanyak ialah Pseudomonas aeruginosa (46,1\%), diikuti oleh Escherichia coli $(15,4 \%)$, Enterobacter hormaechei $(7,7 \%)$, Alcaligenes faecalis (7,7\%), Enterobacter cloacae (7,7\%), Bacteroides fragilis (7,7\%), dan Proteus mirabilis (7,7\%).

Tabel 4 memperlihatkan distribusi jenis kuman berdasarkan tindakan operasi. Dari 11 tindakan laparotomi ditemukan 2 sampel positif Escherichia coli, 1 sampel positif Enterobacter cloacae, Bacteroides fragilis, dan Proteus mirabilis, serta 6 sampel positif Pseudomonas aeruginosa. Pada 2 tindakan ORIF ditemukan masingmasing 1 sampel positif Enterobacter hormaechei dan Alcaligenes faecalis.

Tabel 3. Distribusi jenis kuman hasil PCR

\begin{tabular}{lccc}
\hline \multicolumn{1}{c}{ Jenis kuman } & $\begin{array}{c}\text { Penggolongan berdasarkan } \\
\text { pengecatan Gram }\end{array}$ & Frekuensi & Persentase \\
\hline Enterobacter hormaechei & negatif & 1 & $7,7 \%$ \\
Alcaligenes faecalis & negatif & 1 & $7,7 \%$ \\
Escherichia colli & negatif & 2 & $15,4 \%$ \\
Enterobacter cloacae & negatif & 1 & $7,7 \%$ \\
Bacteroides fragilis & negatif & 1 & $7,7 \%$ \\
Proteus Mirabilis & negatif & 1 & $7,7 \%$ \\
Pseudomonas aeruginosa & negatif & 6 & $46,1 \%$ \\
Total & & 13 & $100 \%$ \\
\hline
\end{tabular}

Tabel 4. Distribusi jenis kuman hasil PCR berdasarkan tindakan operasi

\begin{tabular}{lcc}
\hline \multicolumn{1}{c}{ Jenis kuman } & \multicolumn{2}{c}{ Tindakan operasi } \\
& Laparotomi & ORIF \\
\hline Escherichia coli & 2 & 0 \\
Enterobacter hormaechei & 0 & 1 \\
Alcaligenes faecalis & 0 & 1 \\
Pseudomonas aeruginosa & 6 & 0 \\
Enterobacter cloacae & 1 & 0 \\
Bacteriodes fragilis & 1 & 0 \\
Proteus mirabilis & 1 & 0 \\
\hline
\end{tabular}

\section{BAHASAN}

Infeksi merupakan hasil masuknya, pertumbuhan dan perkembangan dari mikroorganisme di dalam jaringan, yang berakibat perubahan metabolisme dan fisiologi dari jaringan itu sendiri. Infeksi luka operasi (surgical site infections) didefinisikan sebagai infeksi yang terjadi sampai 30 hari setelah tindakan pembedahan, atau sampai 1 tahun setelah tindakan pembedahan pada pasien yang dilakukan implan. Insidensi infeksi luka 
operasi ditemukan sekitar $20 \%$ dan tergantung pada prosedur pembedahan, kriteria yang dipakai, dan kualitas data yang terkumpul. ${ }^{9}$

Pada penelitian ini dilakukan pemeriksaan cairan pus dengan menggunakan metode PCR pada 16 infeksi luka operasi dari pasien multitruma di ruang perawatan bedah RSUP Prof. Dr. R. D. Kandou Manado. Hasil pemeriksaan dengan metode PCR mendapatkan 13 sampel positif kuman dari 7 jenis kuman, yaitu: Enterobacter hormaechei, Alcaligenes faecalis, Escherichia coli, Pseudomonas aeruginosa, Enterobacter cloacae, Bacteroides fragilis, dan Proteus mirabilis. Terdapat 3 sampel dengan PCR negatif, artinya tidak ditemukan kuman pada luka operasi. Pada penelitian ini digunakan metode PCR yang mendapatkan hasil lebih cepat dibandingkan dengan metode lain dengan angka sensitifitas dan spesifitas $99 \% .^{5}$ Hasil penelitian ini mendapatkan kuman tersering ialah, Pseudomonas aeruginosa diikuti oleh Escherichia coli. Hal ini tidak sepenuhnya sejalan dengan pernyataan Owen dan Stoessel ${ }^{9}$ yang melaporkan mikroorganisme tersering diisolasi ialah Staphylococcus aureus, coagulase-negative staphylococci, Enterococcus spp, dan Escherichia coli. Hasil penelitian ini tidak selaras dengan laporan hasil penelitian retrospektif dari Cantlon et al. ${ }^{10}$ terhadap kejadian infeksi luka operasi di beberapa rumah sakit baik di pedalaman maupun di kota di Midwest yang mendapatkan Staphylococcus aureus sebagai patogen yang paling sering diikuti oleh Enterobacteriaceas, streptococci sp, coagulase negative staphylococci, enterococci sp, dan Pseudomonas aeruginosa; juga ditemukan MRSA tetapi dalam jumlah kecil. Hasil penelitian Wolcott et al. ${ }^{11}$ di Texas terhadap infeksi luka operasi kronis dengan menggunakan bacterial tag-encoded FLX amplicon pyrosequencing (bTEFAP) yang divalidasi dengan quantitative polymerase chain reaction (qPCR) melaporkan terdapatnya uncharacterized bacteriodales sebagai populasi dominan di semua infeksi luka operasi, 60\% tergolong bakteri anaerob, dan kuman multispesies pada setiap luka operasi terinfeksi.

Pseudomonas aeruginosa merupakan kuman yang paling sering ditemukan dengan jumlah 6 sampel $(46,1 \%)$ sedangkan kuman lain hanya ditemukan pada 2 sampel Escherichia coli, dan masing-masing 1 sampel Enterobacter hormaechei, Alcaligenes faecalis, Enterobacter cloacae, Bacteroides fragilis, dan Proteus mirabilis. Hasil tersebut dapat memberikan gambaran pola kuman pada infeksi luka operasi di ruang perawatan bedah RSUP Prof. Dr. R. D. Kandou yang ternyata tidak sejalan dengan laporan hasil penelitian di negara lain.

Pseudomonas aeruginosa merupakan basilus Gram negatif yang motil dan hidup dalam suasana aerob. Bakteri ini membentuk koloni pada manusia dan menimbulkan infeksi bila fungsi pertahanan tubuh abnormal. Oleh karena itu Pseudomonas aeruginosa disebut patogen oportunistik, yaitu memanfaatkan kerusakan pada mekanisme pertahanan tubuh untuk memulai suatu infeksi. Bakteri ini tinggal pada manusia yang normal dan berlaku sebagai saprofit pada usus halus dan kulit manusia. ${ }^{6}$

Pseudomonas aeruginosa memroduksi sitotoksin dan protease (antara lain eksotoksin A dan S, hemolisin, dan elastase). Isolat dari pasien fibrosis kistik menghasilkan alginat polisakarida. Hal ini memungkinkan terbentuknya mikrokoloni di mana organisme terlindung dari opsonisasi, fagositosis, dan antibiotik. ${ }^{7}$ Pada laparotomi didapatkan hasil kuman Pseudomonas aeruginosa masih tinggi; hal ini dimungkinkan karena sampel diambil di ruang sehingga rentan terhadap kontaminasi bakteri flora normal usus. Bakteri ini akan berubah menjadi patogen dan menyebabkan infeksi bila berada di luar habitat normalnya misalnya pada kulit luka operasi. ${ }^{8}$

Pada analisis data didapatkan hasil sampel positif yang masih tinggi pada operasi laparatomi dan ORIF; hal ini mencerminkan bahwa masih tingginya 
infeksi kuman pada pasien dengan infeksi luka operasi. Hasil ini dapat dipengaruhi oleh beberapa faktor: antara lain: faktor ekstrinsik dari luar misalnya kebersihan alat kedokteran dan lingkungan sekitar rumah sakit yang kontak langsung dengan kuman; serta faktor intrisik, antara lain usia (semakin tua usia, semakin besar risiko terkena infeksi) dan gizi (gizi buruk lebih mudah terkena infeksi). ${ }^{5}$

Ditemukannya bakteri Pseudomonas aeruginosa sebagai penyebab tersering dari infeksi pasca operasi pada penelitian ini mungkin disebabkan karena bakteri ini merupakan flora normal pada usus dan kulit manusia. Selain itu Pseudomonas dapat tumbuh subur pada cairan desinfektan, sehingga bakteri ini sangat mudah menyebar dengan cepat pada pasien maupun lingkungan rumah sakit. ${ }^{5}$

Penyebab infeksi yang masih tinggi dapat disebabkan dari autoinfeksi yaitu bakteri yang memang sudah terdapat di dalam tubuh manusia dan berpindah ke bagian lain dari tubuh atau yang berasal eksogen dari lingkungan rumah sakit seperti udara ruang operasi, peralatan yang tidak steril, maupun petugas rumah sakit yang kurang menerapkan perilaku aseptik dan antiseptik. Untuk mengurangi terjadinya infeksi, ruangan operasi setiap akan digunakan wajib disterilkan terlebih udaranya, mempunyai ventilasi yang baik, lantai disapu dan dibersihkan setiap hari, serta kebersihan tempat tidur diperhatikan. Peralatan yang steril dan petugas yang bekerja secara aseptik antara lain sterilisasi semua peralatan yang digunakan di ruang operasi, tindakan cuci tangan, serta pemakaian alat pelindung diri dengan benar sangat berperan dalam mencegah terjadinya infeksi pada luka operasi. ${ }^{8}$

\section{SIMPULAN}

Dari hasil penelitian terhadap infeksi luka operasi pada pasien multitrauma di RSUP Prof. Dr. R. D. Kandou Manado pada bulan Juni 2016 - Desember 2016, berdasarkan hasil PCR didapatkan 7 jenis kuman pada infeksi luka operasi dari pasien multitrauma, kesemuanya tergolong bakteri
Gram negatif, dan yang tersering ialah Pseudomonas aeruginosa.

Hasil PCR yang negatif pada sebagian kecil sampel mungkin disebabkan oleh desinfeksi yang baik sebelum operasi dan prosedur operasi yang cukup steril mengingat terjadinya suatu infeksi diakibatkan oleh virulensi kuman tersebut dan daya tahan penderita.

\section{SARAN}

Dengan perawatan luka yang baik maka akan didapatkan hasil yang maksimal sehingga dapat menghindari atau menekan kejadian infeksi pasca operasi antara lain oleh kuman-kuman yang oportunistik yang pada keadaan tertentu atau dengan penyakit dasar yang lain akan berubah dari nonpatogen menjadi patogen.

\section{DAFTAR PUSTAKA}

1. Sjamsuhidajat R, de Jong W. Infeksi. Buku Ajar Ilmu Bedah (2nd ed). Jakarta: EGC, 2004.

2. Nichols RL. Infeksi bedah dan pemilihan antibiotika. Sabiston Buku Ajar Ilmu Bedah. Jakarta: EGC, 1992; p. 176211.

3. Bailman G, Dunn D. Surgical infections. Schwarzts Principles of Surgery (10th ed). New York: Mc Graw-Hill, 2015.

4. Nucki NH. Pencegahan infeksi luka operasi. Available from: http://pustaka.unpad.ac.id/wpcontent/uploads/2009/04/pencegahan_i nfeksi_luka_operasi.pdf

5. Barie PS. Surgical site infections: epidemiology and prevention. Surg Infect (Larchmt). 2002;3 Suppl 1:S921.

6. Euparelia JP, Chatterjee AK, Duttagupta SP, Mukherji S. Strain specificity in antimicrobial activity of silver and copper nanoparticles. Acta Biomaterialia. 2008;4(3):707-16.

7. Irianto K. Bakteriologi, Mikologi \& Virologi: Panduan Medis 7 Klinis. Bandung: Alfabeta, 2012; p. 78-9.

8. Nichols RL. Surgical infection: prevention and treatment - 1965-1995. Am J Surg. 1996;172:68-74.

9. Owens CD, Stoessel K. Surgical site infections: epidemiology, microbiology 
120 Jurnal Biomedik (JBM), Volume 9, Nomor 2, Juli 2017, hlm. 115-120

and prevention. J Hosp Infect. 2008;70 Suppl 2:3-10.

10. Cantlon CA, Stemper ME, Schwan WR, Hoffman MA, Qutaishat SS. Significant pathogens isolated from surgical site infections at a community hospital in the Midwest. Am J Infect Control.
2006;34(8):526-9.

11. Wolcott RD, Gontcharova V, Sun Y, Zischakau A, Dowd SE. Bacterial diversity in surgical site infections: not just aerobic cocci any more. $\mathrm{J}$ Wound Care. 2009;18(8):317-23. 